\title{
Craft Theory in Prehistory: Case Studies from the Mesolithic of Britain and Ireland
}

\author{
By BEN ELLIOTT
}

This paper reflects critically on the use of the term 'craft' within prehistoric archaeology and its recent rise to prominence within a variety of analytical contexts. Having briefly evaluated the way in which prehistorians employ craft, it moves on to consider the potential value that Craft Theory, a growing interdisciplinary body of literature relating to practices of making, might hold for thinking about prehistoric material culture within an archaeological context. Three case studies originating from Mesolithic Britain and Ireland are used as a vehicle to explore some of this potential in practice, before a broader discussion reflects on these initial efforts and sketches out other areas of interest for future research. The picture which emerges from this discussion is one of promise, within which prehistorians simultaneously draw from, and contribute towards, the ongoing interdisciplinary debates on craft in contemporary society.

Keywords: craft, making, makers, material culture theory, Mesolithic

Recent years have seen a notable growth in the use of the term 'craft' within prehistoric discourse, albeit within a set of specific analytical contexts. Given the popular social meanings associated with the word craft, it seems apt to reflect critically on its rise within archaeological research and consider some of the challenges that a general understanding of the term pose for our prehistoric narratives. In taking a step back to view the wider role that craft is starting to play in our conceptualisation of prehistoric material culture, it may also be timely to consider what else the term could offer archaeology. A wider body of literature concerned with the many manifestations of craft in art history, sociology, anthropology, design theory, and social geography has developed over the course of the past 200 years. This work falls loosely around three core themes: makers, making, and things made. The ideas emerging from these discussions are eclectic and often contradictory, reflecting a diverse set of perspectives which address the practice of making within an equally wide range of material, cultural, chronological, and geographical contexts. Archaeology has, at best, taken a back seat in these debates to date. This paper will begin to outline some of the ways in which concepts developed under the craft theory umbrella might be used to widen our understanding of early prehistoric material culture. In order to do this, three examples of artefacts from the Irish and British Mesolithic will be explored from a series of alternative perspectives laid out by the interdisciplinary discussions on craft. In considering the theoretical roots of these approaches, further potential uses for craft theory within early prehistory will be identified, alongside ways in which archaeology can begin to actively contribute to the ongoing craft theory debate.

\section{THE RISE OF CRAFT IN LATER PREHISTORIC STUDIES}

Whilst use of the term 'craft' within discourse on early prehistory (Mesolithic/Neolithic) remains sparse, that on later prehistory (Bronze/Iron Age) has seen a notable increase in recent years. At the forefront of this rise are the emergent approaches of Cross Craft Interaction (CCI), communities of practice, microwear analysis, and a reappraisal of the concept of skill in relation to the development of central European metalworking. The CCI approach to prehistoric societies 
has triggered a notable increase in the use of the term 'craft' within later prehistoric/Classical discourse. CCI is an approach to the study of technological information transmission, highlighting the similarities in the chaîne opératoire of contemporary forms of material culture. Spearheaded by the work of Brysbaert (2014), this approach has been applied primarily in the context of Classical specialised material culture production, deconstructing many of the assumptions associated with the concept of a 'workshop' within the Classical world. It has focused on the moments in which ideas transfer from one material to another, and the social and spatial contexts which facilitate these transferences.

CCI uses the term 'craft' to denote the production of material culture and encompasses a wide range of materials and forms within its analytical lens. Whilst more recent work has broadly acknowledged the complex character of craft theory, and the relevance of CCI to a growing cultural concern with craft (Brysbaert 2017), this simple definition of craft as making material culture has been retained. And with good reason; the strength of CCI comes from its ability to encompass making in a wide range of material forms and social contexts, and the inclusive character of this simple definition allows for hitherto undiscovered links and transferences to be identified. This has enabled CCI studies to explore the interconnected nature of a network of social actors across the Classical world, leading to new insights into the transmission of ideas and knowledge across large and culturally diverse areas of southern Europe (Rebay-Salisbury et al. 2014).

Despite not being the primary focus of research, the lexicon of craft has also filtered through into archaeological approaches to communities of practice (Wendrich 2012). Drawing primarily from the pedagogy of Lave and Wenger (Lave 1988; Lave \& Wenger 1991; Wenger 1998), these approaches emphasise the role of informal and peripheral learning in the transmission of cultural knowledge. This places a focus on the context of learning within past societies, the structure of 'apprenticeship' relations, and (ultimately) the mechanisms through which specific cultural traits are replicated through time. As such, anthropological and archaeological approaches to the study of communities of practice often feature detailed descriptions of specific making processes and analysis of their social contexts. Within these studies, terms such as 'craft/technology/making/material culture production', 'craftsman/maker/producer', and 'craftsmanship/skill/making practice' are used almost interchangeably. Little focus is placed on the precise definition of the term craft itself, and this, coupled with a fluid approach to the terminology outlined above, means that the extent to which explicit craft lexicon features within the writings of different authors varies depending on the academic context and personal writing style. For example, the huge difference in the frequency of the term 'craft' between the work of Høgseth (2012) and Milne (2005; 2012) is a reflection of each author's respective style, rather than a radically different approach or research agenda. This attitude towards the use of the term craft within the study of communities of practice is understandable, and does not significantly inhibit the various researchers who have taken this approach from developing an anthropologically-nuanced and materially-informed understanding of past learning structures.

Elsewhere, the recent growth of microscopic and biochemical approaches within usewear studies has further fueled the use of the word craft within discussions of prehistoric lifeways. Primarily driven by the work of Van Gijn and her colleagues at Leiden's Material Culture Laboratory, these approaches have generated new understandings of the roles that a range of material culture forms played in the prehistoric past. Within the context of analysis which seeks to identify contact materials, actions and gestures, craft has become a shorthand 
term, used to denote human action carried out in the production of material culture (van Gijn 2010). This definition is, by necessity, well suited for the categorisation of microscopic evidence of past human actions, with microtraces relating to the working of plant, bone, hide, and woody materials being grouped together in a way which allows the making of objects to be distinguished from other types of tasks and activities. The general utility of this broad approach to craft is offset by some acknowledged limitations when dealing with the social nuance of craft as practice (van Gijn 2010, 76). A direct consequence of this approach is that craft is often defined in opposition to the procurement of raw materials and food processing tasks (van Gijn \& Little 2016, 144-5), which might otherwise be considered crafts in their own right. The heavy (although not exclusive) focus of microwear studies on flint tools can also skew this definition of craft towards the production of non-flint artefacts - leaving the craft of flint tool making itself strangely disconnected from broader discussions of craft in prehistoric life.

When considering the making of material culture as a shared social practice, microwear analysts tend to revert to the term 'technological tradition'. Technological traditions are seen as specific ways of making material culture which are maintained over prolonged periods of time and become embedded within concepts of group identity (van Gijn 2010, 83). Once defined, these traditions feed into narratives of normative cultural identity and the reiteration of cultural historic distinctions between specific archaeological signatures. This allows instances of craft, identified through microwear analysis, to be positioned in relation to wider debates concerning the maintenance and transformation of identity within later prehistory (van Gijn 2010, 106-7).

Kuijpers $(2015 ; 2018)$ uses the terms craft and craftsmanship frequently when outlining his approach to the study of Bronze Age metalworking - proposing craft as a more fitting alternative to technology within this particular context. This critique of the relationship between discursive and non-discursive knowledge in the historiography of prehistoric metalworking leads towards a specific focus on the concept of skill, and the role sensory experience plays in the development and practice of a range of skills associated with metalworking. However, it is notable that within his discussion, whilst referencing the growing attention paid to craft as a concept (Kuijpers 2015, 147; 2018), his focus falls squarely on the embodied elements of skill which are involved in early metalworking. He uses an understanding of these elements of skill to define conventional typologies of bronze axe types based on the sensory experiences involved in their making, rather than their form in the archaeological record (Kuijpers 2018). As such, although Kuijpers' (2018) work draws directly from craft theory in its relation to embodied skill, other concepts and ideas derived from this movement remain overlooked within a prehistoric context.

\section{CAUTION IN CRAFTING}

The above review demonstrates that the use of the word 'craft' within prehistoric studies is on the rise. But is this a problem in itself? I have argued that in each case, craft is defined in a manner specific to the questions being asked, and it meets the needs of both the theoretical frameworks within which researchers operate and the forms of data with which their analyses deal. More generally, prehistorians tend to use the term craft at the expense of technology or industry when they wish to emphasis the skilled, small-scale, and socially embedded character of material culture production in past societies. Craft offers one way to circumvent the cartesian distinctions of culture/nature implied by technology, and the economic, ahistorical implications of the word industry. Craft is used for a reason; it holds a series of connotations within 
contemporary society which, to varying degrees, have been harnessed within archaeological writing.

However, a broader reading of the craft theory literature suggests that critical reflection on our use of this term may offer some cause for caution; as well as new avenues down which to explore craft in prehistoric contexts. Brysbaert points out that using the term 'craft' uncritically can be problematic for archaeologists, as it is a word which carries with it a series of social connotations within popular culture. Adamson $(2007,1)$ likens this popular understanding of craft to the word colour; 'like color [sic], craft is a word that most people think they understand a commonsense term. Yet both have been subject to considerable speculation.' The historical roots of the popular conception of craft have also been intensively critiqued. Adamson builds a sophisticated argument for both the philosophical and economic interdependence of craft and industry within modernist ideologies (Adamson 2013), and this raises serious questions concerning the applicability of a populist, 21st century understanding of craft within prehistoric contexts.

Beyond the academic and practitioner-led debates alluded to by Adamson, a further consideration is the growing commercialisation of the term craft within western societies. Exploiting the romantic and moralistic overtones of the 19th century arts and crafts movement, mass marketing techniques have been used to shape popular understandings of craft for the purposes of improving brand perception and public image. This has formed part of the broader trend of what Kennedy (2013) terms the 'cupcakification' of rural identity; a co-ordinated commercial manipulation of the public understanding of rural landscapes and lifestyles which encompasses concepts such as 'organic', 'locally-sourced', 'community', and 'artisan' (Groom 2013). With tacit definitions of craft falling squarely within the realm of aspirational, middle class, and 'hipster' market personas (Greenlees 2016; Morris 2017; Samadder 2018), it is worth bearing in mind that the connotations associated with this term are being actively manipulated within consumer societies. As such, it may well be prudent to take a more critical approach to our growing use of this term within archaeological discourse.

\section{A BROADER READING OF CRAFT THEORY}

Whilst Kuijpers' (2018) discussion of craft theory provides a broad and well-informed context for his approach to embodied skill in metalmaking, there remain large areas of literature concerned with craft which are yet to be explored in relation to archaeology. A key characteristic of this literature is its eclecticism; the relationship between makers, making, and things made has been considered from a huge range of perspectives and for a variety of purposes. As a direct consequence of this, there is little intellectual middle ground on which all authors would agree. The ethical and moralist arguments of romantic political philosophers such as Morris (1915) and Ruskin (1892) are directly contradicted by Pye's (1968) experiences as a design teacher and Miller's (2011) anthropological observations of non-mechanised production within the developing world. The arguments on craft work and material engagement advocated by Ingold (2011) and Sennett (2008) are contested by the anthropological observations of Yarrow and Jones (2014). The roles of discursive and non-discursive knowledge proposed by Niedderer (2009) directly contract with those of Gropius (1992), which underlay the highly influential Bauhaus movement in design.

The point being made here is that, even amongst the literary and materially wellinformed, universally accepted definitions of what craft is, what craft does, and how craft happens, are impossible to come by (Nakashima 2010,1). However, this is not to say that this 
literature is not of value to archaeologists. It can be argued that this intense multivocality within the craft theory debate is one of its major strengths; such a wide range of informed perspectives on makers, making, and material culture offers some fascinating alternatives to the critiqued concept of a singular 'western', 'modern', or 'postmodern' attitude towards material culture. Whilst these alternative attitudes might not make for particularly suitable sources of direct analogy for prehistoric societies, the net effect of the diversity of voices within this literature is that it retains a critical handle on issues such as agency (eg, Nakashima 2010), personhood (eg, Alasheev 1995), and gender (eg, Black \& Burisch 2010; 2018). The lack of singularity within this body of research allows for the development of a more critically reflective discourse.

Consequently, craft theory is perhaps best approached as less of a source of authoritative definitions or a set theoretical framework to be followed, and more as a pool of ideas and concepts to be explored and reflected upon in relation to archaeological materials. The following section will take three examples of early prehistoric material culture - all from British and Irish Mesolithic contexts - and explore them in relation to distinct concepts which have emerged from craft theory discourse. This will be followed by a short comparative discussion which draws out further potential for the application of craft theory and sketches a road map for the future role of craft theory within early prehistoric archaeology.

\section{CRAFTED APPROACHES TO EARLY PREHISTORIC MATERIAL CULTURE}

\section{Making uniserial barbed points from red deer antler}

One area in which there appears to be the most widespread agreement within the literature concerning craft is the role that 'making practices' play in underpinning an understanding of materiality. This is articulated in a huge variety of ways: that we do not fully understand the things that we have not made ourselves (Sennett 2008, 7); that there is a distinction between the understandings of makers and consumers (Ingold 2011, 26; Olsen 2013); that the way we approach the repair and maintenance of objects changes when we have not made them ourselves (Yarrow \& Jones 2014); that the intended meaning of an object can be concealed from those who do not know how it has been made (Morris 1970; Phillips 1989); or that the behaviour of materials during making directly influences the makers' relationship with the finished object (Nakashima 2010). Underpinning all of these ideas is a core concept-making things changes our understanding of the things that we make (Risatti 2007, 14).

Archaeologically, the conceptually transformative effects of making are recognised in the invaluable contribution of experimental approaches to our understanding of material culture. A good example of this comes from the author's own work at the Early Mesolithic site of Star Carr, Yorkshire, UK (Elliott \& Little 2018; Elliott \& Milner 2010; Elliott et al. 2018). Here, outstanding questions concerning the on-site manufacture of antler projectile points were addressed through the discursive and non-discursive knowledge gained in making the objects themselves (Fig. 1). Through the process of making, it became apparent that the types of manufacturing waste previously postulated were obsolete, and that the skills and techniques used in making different types of projectiles were identical. Making also highlighted the mechanical strength of the finished objects, casting new light on the specific breakage patterns observed at Star Carr, which would have required considerably more force and direction than had previously been postulated. At a more general (but no less valuable) level, the experience gained through these experiments helped to inform a better understanding of the time and skills needed to repair broken artefacts, and the point at which damage made repair impossible. 
As such, making barbed points has played a key role in our understanding of these objects, and the roles they may have played in Early Mesolithic life. This link between experiences gained through making and an understanding of the thing made is a key theme within craft theory, and these experiences can help us to reflect critically on the kinds of knowledge that experimental approaches to prehistoric material culture offer us. Firstly, this example highlights the fact that, whilst experimental work might lead to a better-informed understanding of a piece of material culture, this understanding can never be used as a direct analogy for those working in the past. As experimental archaeologists living within a consumerist society, our understanding of the material culture we produce stands apart from our understanding of the vast majority of our material world. The fact that we have made these objects ourselves infuses them with a novelty status which is unlikely to be shared by people who make a much larger proportion of that material culture repertoire. Further experimental work at Star Carr (Little et al. 2016), combined with the distribution of material culture and manufacturing waste (Conneller et al. 2018), suggests a general lack of specialised production at the site, with the vast majority its inhabitants possessing the skills required to create flint tools, set fires, work wood, butcher animals, process hide, and build structures (Taylor et al. 2018). As such, the making of antler projectile points can be seen in the context of a community where most people were involved in the making of most things. This is a direct contrast to the experiences of experimental archaeologists operating within a consumerist context, and if making things changes our understanding of the things we make, this key distinction suggests fundamentally different understandings of the material world.

Other areas of craft theory can help us further reflect upon the different kinds of knowledge generated in the making of archaeological material culture. The refined methodologies of cultural geographers who have used experiment to investigate specific craft histories may be of some interest in this regard. For instance, Patchett's (2016) work on taxidermy highlights the tensions created by learning from both historical textbooks and a living mentor and explores the ways in which these tensions inform, but do not dictate, the development of her own taxidermy practice. Patchett highlights the role of material 'exposures' in her learning - working with images and text from 19th century handbooks and studying other taxidermy specimens far more often than she spoke to her tutor. In this context, she argues that craft practices resonate, rather than reproduce themselves through time. This is seen again in the work of Mann (2017) on the production of Shetland lace, and the ways in which material culture can inform the acquisition of new skills within an experimental context. Hill (2014) takes an alternative approach in her study of charcoal burning practices, focusing on the different forms of time bound up in this particular communal craft activity. Describing a charcoal burn within the Forest of Dean, Hill reflects on the historical roots of this practice, the development of our understanding of the process based on involvement in previous years burns, and its current status as a heritage workshop. She argues that the temporality of this act, being repeated seasonally year on year, creates a series of connections with past repetitions and draws both the past and the future together through communal practice.

Crucially, all three of these authors develop methodologies which critically link the knowledge of craft gained through experiment in the present, back to understandings of craft in the past. Patchett's use of material exposures is particularly interesting in this regard, and draws comparisons with the ways in which experimental archaeologists use the archaeological record to inform the development of their own craft skills, and the tensions this can create when taught by contemporary craft practitioners. Patchett tackles this challenge positively, developing a 
methodology which not only acknowledges these tensions, but feeds them back constructively into a critically informed understanding of craft practices in the past.

Within the context of the Star Carr barbed points, experiments were designed and executed following a detailed study of the artefacts and debitage from the site, alongside the excavation report. Advice from archaeologists with prior experience in working with flint and antler was occasionally sought. These sources of information can be seen to be broadly analogous to Patchett's relationship to her material exposures and taxidermy mentor. As such, we might consider both the making practice developed within the experiments, and the understandings of past material culture gained through experimental work, to resonate with those of people in the past, rather than replicate them. We might say that there is a resonance between the non-discursive understandings of the barbed point making gained during the experimental process; knowledge of the time and effort required to learn the necessary skills, the physical sensations associated with the task itself, and the specific challenges and difficulties encountered during the experience.However, the experiments in themselves do not privilege the experimenter with a replicated understanding of past material cultures.

\section{Blade core from Forvie}

Whilst blade cores might technically be considered debitage, their ubiquity (in a variety of forms) across the Mesolithic record attests to their common occurrence within the rhythms of everyday life throughout the period. This particular core was recovered from the Sands of Forvie, Aberdeenshire, Scotland. Survey and excavation at this site have identified a series of late Mesolithic flint scatters (alongside evidence for activity in later periods) which suggests that groups of people with varying skill levels visited Forvie to make small blades and microliths, before moving on elsewhere in the landscape. Small flint pebbles and cobbles were gathered locally and quickly worked (often through bipolar knapping) into cores to produce blades and flakes.

Core 10514 is a fine pyramidal core made from a small pebble of honey-coloured flint (Fig. 2). Conventional approaches to Mesolithic material culture might consider the specific techniques used in the making of this core, noting the single striking platform, the ways in which this platform has been maintained during use, and relating these to wider patterns in technological practice at the site and landscape level. Our discussions might consider the source of the flint itself, and the networks of movement required to acquire this material. The extent to which the core has been worked could be used to argue for specific attitudes towards the management of flint within the landscape. Studies of the dimensions of the core and its removal scars might be used to postulate possible uses of the blades removed, as well as the levels of care and control (ie skill) exerted during the working of this piece. The initial lithics report and forthcoming publication from the site explore this material from all of these aspects (Warren forthcoming).

However, several strands of craft theory can be employed to consider this core in new ways. A large proportion of craft theory has been devoted to the debate over the relationship between craft and fine art (Adamson 2007; Collingwood 1938; Pye 1968; Risatti 2007). Although most fiercely contested during the 19th and early 20th centuries, these arguments have continued to develop throughout the later 20th century and into the present, as the nature of both craft and the fine arts themselves shift within the contemporary world. Many of the arguments mooted within this debate revolve around the idea of functional aesthetics or functional beauty the ways in which the functionality of material culture affects its aesthetic. These concepts have 
implications for the definition of creativity and aesthetic expression within archaeological contexts, particularly in relation to decorated material culture (the decorative arts) and objects which were made to be used. These have an acute value in prehistoric contexts which lack formal evidence for artwork or visual culture. Where previous approaches have viewed these absences as evidence of cultural regression, more recent research has struggled with diachronic analysis of prehistoric art across periods of time which lack conventionally recognised evidence for artistic expression. The Scottish Mesolithic is one such context. Whilst most archaeologists would happily acknowledge that Mesolithic life contained an element of creativity and artistic expression (Warren 2005, 106), the lack of preserved material evidence which falls within the conventional categories of 'art' or 'visual culture' prevents any further development of our understanding of these aspects of Mesolithic life. As such, the spectre of a 'cultural hiatus' (Munro 1908) looms over our narrative of prehistoric art in Scotland - the antiquated idea that, between the dizzying cultural heights of Upper Palaeolithic cave art and monumental architecture and rock art of the Neolithic, Mesolithic societies represent some form of regression within the prehistoric sequence.

A functional aesthetic approach to some of the most commonly identified forms of Mesolithic material culture can begin to address this, by developing an understanding of the aesthetic values and creativity expressed through the making of Mesolithic material culture. Of the various approaches to functional aesthetics (Sauchelli 2013; Yanagi 2018), perhaps the most appropriate for application within a prehistoric context is the internalist framework of Parsons and Carlson (2008). This is developed further than the externalist approaches proposed by Kant (Guyer 2002), under which functionality acts as a limit to aesthetics, and avoids the concepts of belief and expectation (Sauchelli 2013), which present specific challenges when working in a prehistoric context. Parson and Carlson $(2008,168)$ argue for a theory of aesthetics which accounts for the pleasure derived from using everyday artefacts and which is not exclusively reserved for experiences gained in art galleries or 'the wilderness'. Everyday aesthetic objects have a function; are experienced through a range of senses; relate people to other elements of the material world; have a limited functional 'life'; and confer meaning in a fundamentally different way to 'fine art' objects. These criteria seem to fit with the majority of Mesolithic material culture, which has been functionally utilised in conjunction with other objects, people and materials, held and seen by people in the past, and eventually incorporated into the archaeological record. Under Parsons and Carlson's approach, an object's functional aesthetics may be analysed from three perspectives: looking fit for purpose; visual tension (contradictions between an object's appearance and its physical properties); and elegance, gracefulness and simplicity.

We can apply these approaches to our Forvie blade core. Core 10514 has had a series of narrow flint blades removed, using a single striking platform, and was used until it was exhausted. Despite reaching the end of its use-life, this core was worked in a way which preserves its symmetry, ensuring that even the final batch of flint blades produced were of an equal width and length. This implies that, during its 'life', it was highly functional - consistently producing blades of predetermined dimensions through a combination of the quality of the material itself and the skill of the worker. There is a visual tension at play here, with the delicacy of the working and removal scars contrasting with its functionality - the core almost appears too delicate to be functional (a characteristic emphasised by its fragile translucence), and yet clearly was used right up until it was deposited. Its diminutive size also attests to a long use-life, creating tension between the core's final form and its former, larger incarnations. When 
considering the visual tension, it is important to note the object's depositional context.

Thousands of years spent within a highly mobile sand dune system has caused considerable sand abrasion to the Forvie material, creating a thick post-depositional lustre across the surfaces of many of the flint artefacts from this site. As such, this lustrous quality must be overlooked if we are to consider the core's visual tension within a Mesolithic context. The elegant qualities of the piece relate to its functionality; its symmetry and regularly spaced facets speak of controlled, successful blade removals. The slight curve at the apex of the core not only gives the form of the core itself a simple, elegant flourish, but also bestows this aesthetic characteristic on the blade removed in the creation of this facet.

This brief example builds on the attention that craft theory draws to the functional aesthetics of everyday objects, and uses a particular model of functional beauty theory (Parsons \& Carlson 2008) to highlight the aesthetic character of mundane material culture within the Scottish Mesolithic, a period of prehistory traditionally believed to be devoid of evidence for formal art, visual culture, or creative expression. A more thorough application of these ideas to the material record of Mesolithic Scotland may help to define a broader sense of Mesolithic aesthetics, which could in turn frame new questions for the appearance of evidence for more formal "art" in the Neolithic, and the aesthetics of Mesolithic and later prehistoric material culture.

\section{Polished shale adze from Hermitage}

The following example comes from recent research at the Irish Early Mesolithic site of Hermitage, Co. Limerick (Little et al. 2017). Here, a polished shale adze (Fig. 3) recovered from a cremation pit has been examined for traces of manufacture and use at both the microscopic and macroscopic level. Macroscopic, technological analysis, informed by experimental experience, has established the geology, primary working methods, and finishing techniques used to make the adze. At some time around $7250 \mathrm{cal}$. BC, a shale adze roughout was created through knapping from both aspects, before being extensively ground against a coarse-grained abrasive surface with the aid of water. A final phase of grinding resulted in the removal of the majority of the flaking scars created in roughing out, and the shaping of the working edge. This also created a lustrous polish across the entire surface of the adze head. Based on experimental work which replicated similar shale axes, the object is estimated to have taken roughly 6 hours to make. Microscopic analysis of the artefact strongly suggests that the adze had been hafted and used for a short but intensive period of wood working. Furthermore, following this period of use, the adze blade was intentionally blunted through transverse cutting with a flint tool. This action rendered the tool useless for further woodworking and preceded the deposition of the object into the cremation pit.

The authors tread carefully in their interpretation of these different scales of analysis, describing the act of blunting as 'an act so discrete that it calls into question the audience (if any) that witnessed it' (Little et al. 2017, 237). However, specific branches of craft theory can help us to consider this tension between scale of action and audience more explicitly.

The concept of 'facture' emerged from a concern with process and making shared by artists such as John Cage, Jackson Pollock, and Marcel Duchamp. Facture became a guiding principle for the Process Art movement of the 1960s and 70s (Morris 1970), and fundamental to several strands of Bauhaus teaching (Wick 2000). Defined by Moholy-Nagy $(1927,239$ ) as 'the way in which something has been produced shows itself in the finished product', facture is also a theme which runs covertly throughout the study of prehistoric material culture. Technological 
analyses of archaeological artefacts hinge on our ability to identify the methods of production at either the macroscopic, microscopic, or biochemical scale through the direct study of the objects themselves. As such, we could argue that facture is a long-established element of archaeological research. Microstratigraphic processes, and the tendency of latter stages of an artefact's biography to obscure or destroy earlier phases of working, are key factors in the technological analysis of any prehistoric material culture.

Considering the Hermitage Adze explicitly from the perspective of its facture places a focus on the visible traces of flaking, which were not removed through fine grinding. These reveal the way in which the adze was initially shaped and tell of the technical decisions made by the maker during this process. Members of a Mesolithic society who understood the principals and material manifestations of percussive lithic technologies would have been able to recognise this with relative ease. Given the apparent importance of lithic technologies within the Irish Early Mesolithic, and the lack of evidence for specialised lithic production, we might assume that a significant proportion, if not all, of the contemporary Mesolithic population would have been able to discern the way in which this artefact was initially worked with a passing glance.

Facture emphasises intentionality; it suggests that this effect was not created due to a lack of time (as the authors originally proposed) but to allow both the overall surface polish to be achieved and the earlier stages of making to be represented in the final form. The use and blunting of the adze play a profoundly different role in the object's facture. Whilst the blunting action in particular appears to have been steeped in meaning, it is notable that its microscopic nature means that it had little impact on the facture of the object itself to the casual Mesolithic observer. To anyone who did not handle or attempt to use the adze, it would have appeared no different. As such, the blunting of this object becomes a profoundly performative act; significant to those who witnessed it, but invisible to others who did not know the action had been carried out. It is an act not reflected in the adze's Mesolithic facture.

Facture, then, helps to frame further questions concerning the roles that materiality and performance play within the biography of this object. It poses specific questions concerning the distribution of different forms of making knowledge within past societies and the extents to which people in the Mesolithic were privy to specific object biographies. It distinguishes between different levels of visibility in the past and reminds us that prehistoric peoples did not have access to the optical microscopes and mass spectrometers upon which our microscale analyses and narratives rely. Their understandings were gained through profoundly different means than analyists working at the microscopic and biomolecular levels.

\section{DISCUSSION}

The previous section illustrates the ways in which specific concepts, developed under the banner of craft theory, can be applied to early prehistoric material culture. Doing so can broaden our understanding of the roles that these objects played in the past, reappraise the analytical techniques and approaches we currently employ, and frame new questions for further research.

The first case study used the idea that making things changes our understanding of the things we make to reflect critically on the different types of knowledge and understanding generated by experimental archaeology, and the ways in which we use this data to inform our understanding of the past. Acceptance of this idea highlights some of the problems encountered when approaching prehistoric material culture from a consumerist perspective (Olsen 2013, 91), regardless of our personal experimental experiences. The vast majority of archaeologists begin their interpretations from a position within a consumerist society, where self-made material 
culture, whilst not wholly absent, is seen somewhat as a novelty. As such, we understand material culture in a fundamentally different way to people in the deep past who made the majority - if not all - of their material worlds themselves. This is a particular problem for approaches which draw from the body of anthropological research concerning the consumption of material culture (Miller 1991; Miller 1998; Miller 2005), ideas developed to address consumption within a consumerist society.

However, the extent to which people in prehistoric societies made their own material culture is seldom explicitly questioned by early prehistorians. Following this line of enquiry further places an acute focus on the moments in prehistory where the structure of making changes within societies - when people begin to make substantially more or substantially less of their material culture repertoire. If making changes the understanding of material culture, then these moments may also mark key shifts in the ways people understand their material world more generally. This particular argument poses a series of further questions regarding the appearance and disappearance of specialised production; the control of knowledge relating to the making of specific material culture forms; and the spatial and social scales at which material culture is produced in prehistory. Considering these questions alongside the previously suggested shifts in the relationship between people and the material world - such as the 'Human Revolution' of the Upper Paleolithic (Mellars et al. 2007), the adoption of agriculture (Renfrew 2007; Thomas 2013; Watkins 2010), or the advent of metallurgy (Kristiansen \& Larsson 2005) may provide further insight and context for these proposed changes.

The interest from cultural geographers in craft histories has been an emergent theme over the past twenty years. Its development is linked to the Non-Representational Theory (NRT) movement, an approach to cultural geography which, rather than striving to generalise largescale patterns, trends, or processes (Thrift 2008), looks to provide descriptions which demonstrate a fidelity to their subjects (Latham 2003). NRT takes a specific interest in the ways in which crafts, as practices of making, are maintained and reproduced over time (Dewsbury \& Bissell 2014; Hill 2014; Latham 2003; Laurier 2014; Patchett 2016; Payne 2017). This concern with the mechanisms by which craft practices appear to remain stable, or change, over prolonged periods of time is also of an acute interest to prehistoric archaeologists (Knuttsson et al. 2018). The attention that cultural geographers pay to intergenerational practices, and the relationship between making, material reference points, skill, and learning (Mann 2017; Patchett 2016) may be relevant to the patterns of material stability observed in the archaeological record and provide an important source of models for the social conditions in which material culture is made in the prehistoric past. Whilst prehistorians might take issue with the use of the term longue durée to describe the time depth of these studies, they demonstrate both a shared interest in plotting the ways crafts change over time and a series of methodologies which critically incorporate experimental work.

This more critical approach to types of understandings derived from experimental archaeology may be of relevance to the body of Mesolithic studies which have been influenced by Heideggarian discussions of phenomenology (Cobb 2007a \& b; Conneller 2005; 2011; Finlay 2000; Harris 2014). Cobb's (2007b) work on Mesolithic material culture in Western Scotland is perhaps the clearest example, citing the 'intimate, sensuous interaction between the knapper and the stone' as a crucial factor within Mesolithic material agency (Cobb 2007b, 128). However, with the exception of Harris (2014), these approaches have so far shied away from directly engaging with archaeological experiments as legitimate ways in which material encounters might be better understood. Patchett's thoughtful consideration of the relationships among material 
cues, social mentorship, and experiences gained during making may offer potential avenues in which the interactions referred to by Cobb might be further explored.

This overlap between archaeological and cultural geographic concerns with the study of making practices, the ways these play out over time, and the use of experimentation to investigate these processes, suggests that this area is ripe for cross-disciplinary investigation. There are also clear parallels here with Jordan's (2015) ethnographic work on micro-variations in hunter-gatherer making practices, and whilst the theory and methods used to analyse these patterns differ dramatically to the NRT approach, the shared aims of these studies are notable.

The functional aesthetics of flint debitage have been explored in the example cited above to provide new insights into creative expression within the Scottish Mesolithic in relation to a simple blade core from Forvie. This obviously represents an isolated example, and more convincing arguments can be developed by extending this approach to encompass a larger range of material culture. A broader understanding of material aesthetics within a specific context would ultimately result in an appreciation of 'the existence and legitimacy of the aesthetic frameworks in which they were produced' (Price 1989, 93). This contextual approach to nonWestern aesthetic systems has been a longstanding focus for cultural anthropologists (eg, Chua \& Elliott 2013; Gell 1998; Price 1989). As argued above, an understanding of aesthetic expression within the Scottish Mesolithic is important to develop - a consideration of functional aesthetics does more than simply dispel the concept of the 'cultural hiatus', which is inadvertently resurrected within narratives of prehistoric art in Scotland that tend to begin with the Neolithic. Acknowledging aesthetics and creative expression within Mesolithic material culture helps to articulate new research questions. If visual expression existed prior to the Early Neolithic, what triggered the shift in medium and style which leads to the preservation of the more formal 'art' that we see appearing in Early Neolithic Scotland? What is the relationship between the forms of visually expressive practices we see in the Early Neolithic, and their predecessors in the Mesolithic? How does this relate to the wider changes in practice and material world that we see at the transition from the Mesolithic to Neolithic? Addressing these questions has the potential to gradually shift the focus of research from a definition of past aesthetic frameworks to an analysis of the social contexts in which aesthetic frameworks are articulated and negotiated - a key distinction within anthropological research into non-Western art (Gell 1998).

This form of analysis is unapologetically subjective, as any consideration of aesthetics inevitably is. However, the subjective nature of this topic has not inhibited critical debate within other academic disciplines, and so there seems no reason to reject this form of discourse within an archaeological context purely on the basis of subjectivity. Indeed, a consideration of aesthetics, of 'taste, experience and vision' played a key role in the recognition of archaeological material by antiquarian researchers during the birth of the discipline itself (Myrone 2007, 101), and therefore forms a fundamental basis for the categories of artefact we study today. Although seldom explicitly acknowledged, our aesthetic appreciation of prehistoric material culture underpins the decisions of excavators, analysts and curators when determining which finds we choose to illustrate, conserve, and exhibit. These choices affect the way specific pieces of material culture are presented both within and beyond academic archaeology, influencing their capacity to become iconic or emblematic of particular times and places. As such, critically considering our understanding of aesthetics remains an important concern for prehistoric archaeology, regardless of the vigorous critique offered by Gell (1998) of the validity of the concept in non-Western contexts. Parsons and Carlson (2008) provide one particular framework 
within which discussions of functional aesthetics can be structured, and this could conceivably be extended to other archaeological contexts for which considerations of creative expression have been previously lacking, or remained rooted within material formally categorised as art and visual culture.

The concept of facture has been employed here to critically reflect on the tension between macroscopic and microscopic analyses and the role that data from these analyses play in conferring meaning upon material culture. The use of facture within art history has highlighted distinctions between researchers who study how objects are made and researchers who study what an object means (Koerner 1999). Yet an explicit consideration of facture presents the opportunity to overcome these divisions; for microscopic and biomolecular approaches to consider their implications for an object's meaning; and for social theorists to reflect on the relationship between their interpretations and an object's physical form.

Facture brings into analytical focus the moments when the methods of production for a piece of material culture are obscured by its makers and users and the implications this has for its understanding by others. There is a parallel here in the work of Finlay (2000), who's consideration of microlith production in Late Mesolithic Ireland highlights the variety of contexts in which specific types of material culture might be displayed to, or concealed from, a wider audience. A consideration of facture also necessitates an appraisal of who encounters an object and the context for these encounters. The facture of an object will vary depending on the levels to which an observer understands the behaviour of the materials used, the specific making techniques involved, and the traces that these create. As such, a consideration of facture in relation to Finlay's argument presents further research questions surrounding the extent to which audiences, when encountering microliths, were able to 'read' the ways in which they had been made. An appreciation of facture therefore complements the approach taken by Finlay, and provides a lens through which issues of audience and understanding might be more critically considered.

Within art theory, the intentionality of facture is never questioned, and this highlights the potential for integrating ideas of intentionality and human agency when discussing microstratigraphy in prehistoric material culture. Do acts such as the polishing, grinding, or pecking of coarse stone tools have a dual purpose, in creating both a new type texture to the finished artefact as well as deliberately obscuring the methods used in the extraction of raw material and primary working? Were artefacts which present challenges for conventional forms of macroscopic technological analysis made in a way which intentionally masks the techniques of their production from their prehistoric audience? Is this of more relevance at sites or in landscapes where finished artefacts are being imported, rather than sourced, made, and deposited locally? Are artefacts with certain kinds of facture treated differently within the archaeological record in terms of their use, maintenance, and deposition? Many of these questions, particularly those concerned with the relationship between specific phases of making, chime with the concepts of collage, montage, erasure, and superimposition outlined by Cochrane and Jones in relation to Neolithic visual culture (Cochrane \& Jones 2012a, Jones et al. 2015). However, facture stands distinct from these approaches in two respects. Firstly, within the context of craft theory discourse, facture has been applied to a broad spectrum of material culture forms, from sculpture to furniture to cutlery (Adamson 2007). As such, it has a relevance for archaeology which extends beyond the realms of visual culture (Cochrane \& Jones 2012b; Cochrane \& Jones 2018). Although the terms 'art' and 'visual culture' are eschewed by many of those currently exploring these themes, it is notable that their application has to date been heavily focused on 
figurines and rock art (Cochrane \& Jones 2012b). Within this relatively narrow range of materials, these concepts would struggle to influence our understanding of the British and Irish Mesolithic (Milner et al. 2016), or any period which lacks conventionally recognisable visual culture or art. Secondly, facture places the focus of analysis explicitly on the process and techniques of making. Narratives of meaning are inextricably entangled with understandings of making, directly integrating interpretation with conventional forms of technological analysis. Whilst many of the research questions facture poses are ultimately related to context, this core relationship to technology and making may be better suited for the study of material culture that lacks rich contextual data.

\section{CONCLUSIONS}

The preceding discussion has argued that, to date, the concept of craft has been applied critically within a very limited number of prehistoric contexts. However, the ideas and debates emerging from the craft theory movement have the potential to further enrich and expand our discussions of making and material culture in the prehistoric past. Up until now, this potential has remained largely untapped.

At the most general level, the craft theory debate has stressed the idea that making things changes our understanding of the things we make. The full significance of this axiom places an explicit emphasis on our ability to understand the extent to which prehistoric people engaged with the making of the material culture they encountered. It forces us to query the ways in which these levels of engagement with making varied within prehistoric societies, and throughout the prehistoric sequence. Ultimately, pursuing these questions offers archaeologists an opportunity to identify key shifts in the conceptualisation of prehistoric material worlds through the analysis of changes in the ways in which making was structured within past societies.

At a more refined level, the case studies presented above demonstrate that some of the specific concepts to emerge from craft theory have a direct applicability to prehistoric material culture and can be used to generate new understandings and research questions. Facture is one such concept. By focussing on the tensions between microscopic and macroscopic analysis, and the different implications that these have for the ways in which material culture is perceived, facture can help archaeologists to critically examine the different types of knowledge that their analyses produce. In considering the relationship between form and object biography, and the role of the maker in mediating this relationship, facture also helps us to think in new ways about the potential meanings of material cultures within prehistoric societies.

The long running debate over the relationship between craft production and fine art has generated arguments which can help prehistorians to reappraise the ways in which we categorise and analyse visual expression and creativity in the past. Developing and applying concepts of functional aesthetics to prosaic items of prehistoric material culture offers an opportunity to explore aspects of prehistoric life which have so far been reserved for more conventionally recognised forms of figurative and abstract art. This is important for contexts in which those forms are absent from the archaeological record, but also creates the opportunity to develop wider-reaching models of prehistoric aesthetic frameworks, within which visual culture may be situated.

However, the relationship between prehistory and craft theory need not be seen as unidirectional, and prehistorians are uniquely placed to contribute to many of the debates emerging from this field. Some of the clearest areas of cross-disciplinary interest currently come from the work of cultural geographers, whose interest in the ways in which craft practices are 
maintained and reproduced over time are clearly relevant to an understanding of consistency and variation within the archaeological record. However, within cultural geography these debates have so far been limited to historical contexts or specific craft practices which are retained within living social memory. As such, there is clear potential to examine existing craft history narratives (eg, Adamson 2013; Rissatti 2007; Sennett 2008) from a prehistoric perspective, significantly extending their time-depth. Prehistoric archaeology also offers opportunities to further examine the ideas of cultural geographers concerning the mechanism by which craft practices are reproduced. Can we see evidence for 'resonant' practices over what archaeologists might consider to be the longue durée? Do material exposures play a consistent role in influencing craft practices throughout the prehistoric past, or does this vary in different social and historical contexts?

These questions are not straightforward to address, and engaging with them will require significant work in terms of developing suitable analytical approaches and methodologies. However, the dual potential for craft theory to both conceptually enrich current prehistoric research and contribute towards contemporary debates on making, makers, and things made, suggests that investing in the pursuit of these questions may be a productive endeavour for prehistorians.

Acknowledgements: The development of this argument was a somewhat protracted process, taking several years' worth of intermittent thought, conversation, presentation, and revision to reach its present form. Consequently, the list of people who have contributed towards its development is extensive. My initial interest in the relationship between craft theory and Mesolithic material culture emerged from my doctoral research, funded by the AHRC from 2009-12. I was fortunate enough to be given the opportunity to develop these ideas further in 2014, by Graeme Warren and Chantal Conneller, who invited me to present a paper as part of their session Mesolithic Britain and Ireland: 10 Years On at the Manchester Theoretical Archaeology Group conference. After several years of ponderance and enjoyable conversation, the final push to develop these ideas occurred during an IRC Government of Ireland Postdoctoral Research Fellowship at UCD (2017-19). This offered me the opportunity to run a series of seminars supported by the UCD Research Seed Fund, and develop this argument in relation to the application of craft theory within other academic contexts. Contributions to this series from Rose Ferraby, Alex Langlands, Louise Cooke, and Lisa Godson provided much fruitful discussion and heavily influenced my thinking on craft and prehistory. Helpful and constructive comments on early drafts of this paper were provided by Mark Edmonds, Aimée Little, and Graeme Warren. Mel Giles and Caroline Wickham-Jones generously helped with specific suggestions for reading. Aimée Little provided photographs for Figures 1 and 3, and Graeme Warren arranged access to the Sands of Forvie artefacts and site report. Great thanks are also due to my two anonymous reviewers, who provided detailed and insightful feedback on the initial submission. Finally, I wish to thank Julie Gardener for her advice, assistance, and support in developing what is a somewhat unusual paper for PPS. All errors remain my own.

\section{BIBLIOGRAPHY}

Adamson, G. 2007. Thinking through Craft. Oxford: Berg

Adamson, G. 2013. The Invention of Craft. London: Bloomsbury

Alasheev, S. 1995. On a particular kind of love and the specificity of Soviet production. In S. Clarke (ed.), Management and Industry in Russia: Formal and informal relations in the 
Russian industrial enterprise, 69-98. Cheltenham: Edward Elgar

Black, A. \& Burisch, N. 2010. Craft hard, Die free: Radical curatorial strategies for craftivism in unruly contexts. In G. Adamson (ed.), The Craft Reader, 609-619. Oxford: Berg

Black, A. \& Burisch, N. 2018. Craft on Demand: The new politics of the handmade. London: I B Tauris

Brysbaert, A. 2014. Talking shop: Multicraft workshop materials and architecture in prehistoric Tiryns, Greece. In K. Rebay-Salisbury, A. Brysbaert \& L. Foxhall (eds), Material Crossovers: Knowledge networks and the movement of technological knowledge between craft traditions, 37-61. London: Routledge

Brysbaert, A. 2017. Artisans versus nobility? Crafting in context: Introduction. In A. Brysbaert \& A. Gorgues (eds), Artisans vs Nobility: Multiple identities of elites and 'commoners' viewed through the lens of crafting from the chalcolithic to the iron ages in Europe and the Mediterranean, 13-26. Lieden: Sidestone Press

Chua, L. \& Elliott, M. (eds). 2013. Distributed Objects: Meaning and mattering after Alfred Gell. Oxford: Berghahn

Cobb, H. 2007a. Media for movement and making the world: Exploring materiality and identity in the Mesolithic of the Northern Irish Sea Basin. Internet Archaeology, 22

Cobb, H. 2007b. Mutable materials and the production of persons: Reconfiguring understandings of identity in the Mesolithic of the northern Irish Sea basin. Journal of Iberian Archaeology 9/10, 123-36

Cochrane, A. \& Jones, A. 2018. Materials, process, image: The art of Neolithic Britain and Ireland. In A. Cochrane \& A. Jones (eds), The Archaeology of Art: Materials, practices, affects, 137-172. London: Routledge

Cochrane, A. \& Jones, A. 2012a. Visualising the Neolithic: An introduction. In Cochrane \& Jones $2012 b, 1-14$

Cochrane, A. \& Jones, A. (eds). 2012b. Visualising the Neolithic: Abstraction, Figuration, Performance, Representation. Oxford: Oxbow

Collingwood, R. 1938. The Principles of Art. Oxford: Clarendon Press

Conneller, C. 2005. Moving beyond sites: Mesolithic technology in the landscape. In N. Milner \& P. Woodman (eds), Mesolithic Studies: At the Beginning of the 21st Century, 42-55. Oxford: Oxbow

Conneller, C. 2011. An Archaeology of Materials: Substantial transformations in Early prehistoric Europe. Oxford: Routledge

Conneller, C., Little, A. \& Birchenall, J. 2018. Making space through stone. In Milner et al. 2018a, 157-221

Dewsbury, J.D. \& Bissell, D. 2014. Habit geographies: The perilous zones in the life of the individual. cultural geographies 22(1), 21-8

Elliott, B. \& Little, A. 2018. Barbed points. In Milner et al. 2018b, 273-95

Elliott, B. \& Milner, N. 2010. Making a point: A critical review of the barbed point manufacturing process practised at Star Carr. Proceedings of the Prehistoric Society 76, 75-94

Elliott, B., Knight, B. \& Little, A. 2018. Osseous technology. In Milner et al. 2018b, 255-72

Finlay, N. 2000. Microliths in the making. In R. Youngs (ed.), Mesolithic Lifeways: Current research in Britain and Ireland, 23-31. Leicester: Leicester University Archaeology Monographs

Gell, A. 1998. Art and Agency: An anthropological theory. Oxford: Clarendon 
van Gijn, A.L. 2010. Flint in Focus: Lithic biographies in the Neolithic and Bronze Age. Lieden: Sidestone Press

van Gijn, A. \& Little, A. 2016. Tools, use wear and experimentation: Extracting plants from stone and bone. In K. Hardy \& L. Kubiank-Martens (eds), Wild Harvest: Plants in the hominin and pre-agrarian human worlds, 135-54. Oxford: Oxbow

Greenlees, R. 2016. The UK craft sector isn't a 'hipster' economy. It's sparking innovation. The Guardian. Available at: http://www.theguardian.com/commentisfree/2016/nov/18/ukcraft-sector-isnt-hipster-economy-manufacturing [Accessed 3 September 2018]

Groom, N. 2013. 'Let's discuss over country supper soon' - Rural realities and rustic representations. The Clearing. Available at: https://www.littletoller.co.uk/theclearing/lets-discuss-over-country-supper-soon-rebekah-brooks-and-david-cameronrural-realities-and-rustic-representations-nick-groom/ [Accessed 27 February 2018]

Gropius, W. 1992. The theory and organization of the Bauhaus (1923). In C. Harrison \& P. Wood (eds), Art in Theory, 340-46. London: Blackwell

Guyer, P. 2002. Beauty and utility in eighteenth-century aesthetics. Eighteenth-century Studies $35(3), 439-53$

Harris, S. 2014. Sensible dress: The sight, sound, smell and touch of Late Ertebølle Mesolithic cloth types. Cambridge Archaeological Journal 24(1), 37-56

Hill, L. 2014. Time and the practice of charcoal burning. cultural geographies 21(3), 411-27

Høgseth, H. 2012. Knowledge transfer: The craftsmen's abstraction. In W. Wendrich (ed.), Archaeology and Apprenticeship: Body knowledge, identity, and communities of practice, 61-78. Tucson, AZ: University of Arizona Press

Ingold, T. 2011. Being Alive: Essays on movement, knowledge and description. Oxford: Routledge

Jones, A., Cochrane, A., Carter, C., Dawson, I., Diaz-Guardamino, M., Kotuoula, E. \& Minkin, L. 2015. Digital imaging and prehistoric imagery: A new analysis of the Folkton Drums. Antiquity 89(347), 1083-95

Jordan, P. 2015. Technology as Human Social Tradition: Cultural transmission among huntergatherers. Oakland, CA: University of California Press

Kennedy, J. 2013. Terror in the terroir: Resisting the rebranding of the countryside. The Quietus Wreath Lectures. Available at: http://thequietus.com/articles/14114-country-life-britishpolitics-uncanny-music-art [Accessed 27 February 2018]

Koerner, J. 1999. Editorial. RES: Anthropology and Aesthetics 36, 5-19

Knutsson, K., Knutsson, H., Apel, J. \& Glørstad, H. (eds). 2018. Technology of Early Settlement in Northern Europe: Transmission of knowledge and culture. Sheffield: Equinox

Kristiansen, K. \& Larsson, T. 2005. The Rise of Bronze Age Society: Travels, transmissions and transformations. Cambridge: Cambridge University Press

Kuijpers, M. 2015. The sound of fire, taste of copper, feel of bronze and colours of the cast: Sensory aspects of metalworking technology. In M.L. Stig Sørensen \& K. RebaySalisbury (eds), Embodied Knowledge: Perspectives on belief and technology, 137-50. Oxford: Oxbow

Kuijpers, M. 2018. An Archaeology of Skill: Metalworking skill and material specialization in Early Bronze Age Central Europe. Oxford: Routledge

Latham, A. 2003. Research, performance, and doing human geography: Some reflections on the Diary-Photograph, Diary-Interview Method. Environment \& Planning A 35(11), $1993-$ 2017 
Laurier, E. 2014. Dissolving the dog: The home made video. cultural geographies 21(4), 627-38

Lave, J. 1988. Cognition in Practice: Mind, mathematics and culture in everyday life. Cambridge: Cambridge University Press

Lave, J. \& Wenger, E. 1991. Situated Learning: Legitimate peripheral participation. Cambridge: Cambridge University Press

Little, A., Elliott, B., Conneller, C., Pomstra, D., Evans, A., Fitton, L., Holland, A., Davis, R., Kershaw, R., O’Connor, S., O’Connor, T., Sparrow, T., Wilson, A., Jordan, P., Collins, M., Colonese, A., Craig, O., Knight, R., Lucquin, A., Taylor, B. \& Milner, N. 2016. Technological analysis of the world's earliest shamanic costume: A multi-scalar, experimental study of a red deer headdress from the Early Holocene site of Star Carr, North Yorkshire, UK. PloS ONE 11(4), p.e0152136

Little, A., van Gijn, AL., Collins, T., Cooney, G., Elliott, B., Gilhooly, B., Charlton, S. \& Warren, G. 2017. Stone Dead? Uncovering Early Mesolithic mortuary rites, Hermitage, Ireland. Cambridge Journal of Archaeology 27(2), 223-43

Mann, J. 2017. Knitting the archive: Shetland lace and ecologies of skilled practice. cultural geographies 25(1), 91-106

Mellars, P., Boyle, K., Bar-Yosef, O. \& Stringer, C. (eds). 2007. Rethinking the Human Revolution: New behavioural and biological perspectives on the origin and dispersal of modern humans. Cambridge: MacDonald

Miller, D. 1991. Material Culture and Mass Consumption. Oxford: Blackwell

Miller, D. 1998. Material Cultures: Why some things matter. Oxford: Routledge

Miller, D. (ed.) 2005. Materiality. Durham: Duke University Press

Miller, D. 2011. The power of making. In D. Charny (ed.), The Power of Making: The importance of being skilled, 14-29. London: V\&A/The Crafts Council

Milne, S. 2005. Palaeo-Eskimo novice flintknapping in the Eastern Canadian Arctic. Journal of Field Archaeology 30(3), 329-45

Milne, S. 2012. Lithic raw material availability and Palaeo-Eskimo novice flintknapping. In W. Wendrich (ed.), Archaeology and Apprenticeship: Body knowledge, identity, and communities of practice, 119-44. Tucson, AZ: University of Arizona Press

Milner, N., Bamforth, M., Beale, G., Carty, J., Konstantinos, C., Croft, S., Conneller, C., Elliott, B., Fitton, L., Knight, R., Kröger, R., Little, A., Needham, A., Robson, H., Rowley, C. \& Taylor, B. 2016. A unique engraved shale pendant from the site of Star Carr: The oldest Mesolithic art in Britain. Internet Archaeology 40, doi:10.11141/ia.40.8

Milner, N., Conneller, C. \& Taylor, B. (eds). 2018a. Star Carr Volume 1: A persistent place in a changing world. London: White Rose University Press

Milner, N., Conneller, C. \& Taylor, B. (eds). 2018b. Star Carr Volume 2: Studies in technology, subsistence and environment. York: White Rose University Press

Moholy-Nagy, L. 1927. Response to Ernö Kallai. i10 1(6), 227-40

Morris, R. 1970. Some notes on the phenomenology of making: The search for the motivated. ArtForum International, 33-40

Morris, S. 2017. Hats off to craft skills - before they disappear for good. The Guardian. Available at: http://www.theguardian.com/culture/2017/aug/04/hats-heritage-craftsassociation-artisanship [Accessed 3 September 2018]

Morris, W. 1915. Art and industry in the fourteenth century. In M. Morris (ed.), Collected Works of William Morris, 375-90. London: Longmans

Munro, R. 1908. On the transition between the Palaeolithic and Neolithic civilizations in Europe. 
Archaeological Journal 65, 205-44

Myrone, M. 2007. The Society of Antiquaries and the graphic arts: George Vertue and his legacy. In S. Pearce (ed.), Visions of Antiquity: The Society of Antiquaries of London 1707-2007, 99-122. London: Society of Antiquaries

Nakashima, G. 2010. The soul of a tree. In G. Adamson (ed.), The Craft Reader, 219-25. Oxford: Berg

Niedderer, K. 2009. Relating the production of knowledge and the production of artefacts in research. In K. Niedderer \& T. O'Riely (eds), Connections and Reflections: On the relationship between creative production and academic research, 59-68. Helsinki: University of Art and Design Helsinki

Olsen, B. 2013. Material culture after text: Re-remembering things. Norwegian Review of Archaeology 36(2), 87-104

Parsons, G. \& Carlson, A. 2008. Functional Aesthetics. Oxford: Oxford University Press

Patchett, M. 2016. The taxidermist's apprentice: Stitching together the past and present of a craft practice. cultural geographies 23(3), 401-19

Payne, E. 2017. The craft of musical performance: Skilled practice in collaboration. cultural geographies 25(1), 107-22

Phillips, C. 1989. Photography in the Modern Era: European documents and critical writings, 1913-1940. New York, NY: New York Metropolitan Art Museum

Price, S. 1989. Primitive Art in Civilized Places. Chicago: Chicago University Press

Pye, D. 1968. The Nature of Art and Workmanship. Cambridge: Cambridge University Press

Rebay-Salisbury, K., Brysbaert, A. \& Foxhall, L. (eds). 2014. Material Crossovers: Knowledge networks and the movement of technological knowledge between craft traditions. London: Routledge

Renfrew, C. 2007. Prehistory: The making of the human mind. London: Weidenfeld \& Nicolson

Risatti, H. 2007. A Theory of Craft: Function and aesthetic expression. Chapel Hill, NC: University of North Carolina Press

Ruskin, J. 1892. The Nature of Gothic: A chapter of the stones of Venice. London: Kelmscott Press

Samadder, R. 2018. Craft has the power to save us all - a wooden spoon at a time. The Guardian. Available at: http://www.theguardian.com/commentisfree/2018/sep/02/craftmindfulness-welldoing-creative-industry [Accessed 3 September 2018]

Sauchelli, A. 2013. Functional beauty, perception, and aesthetic judgements. The British Journal of Aesthetics 53(1), 41-53

Sennett, R. 2008. The Craftsman. London: Penguin

Taylor, B., Conneller, B., Milner, N., Elliott., Little, A., Knight, R. \& Bamforth, M. 2018. Human lifeways. In Milner et al. 2018a, 245-72

Thrift, N. 2008. Non-Representational Theory: Space, politics, affect. London: Routledge

Thomas, J. 2013. The Birth of Neolithic Britain: An interpretive account. Oxford: Oxford University Press

Warren, G. forthcoming. Excavations at the Sands of Forvie. Edinburgh: Society of Antiquaries of Scotland

Warren, G. 2005. Mesolithic Lives in Scotland. Stroud: Tempus

Watkins, T. 2010. New light on Neolithic revolution in south-west Asia. Antiquity 84(325), 62134

Wendrich, W. (ed.) 2012. Archaeology and Apprenticeship: Body knowledge, identity, and 
communities of practice. Tucson, AZ: University of Arizona Press

Wenger, E. 1998. Communities of Practice: Learning, meaning and identity. Cambridge: Cambridge University Press

Wick, R. 2000. Teaching at the Bauhaus. Stuttgart: Hatje Cantz

Yanagi, S. 2018. The Beauty of Everyday Things. London: Penguin

Yarrow, T. \& Jones, S. 2014. 'Stone is stone': Engagement and detachment in the craft of conservation masonry. The Journal of the Royal Anthropological Institute 20(2), 256-75

Fig. 1. Experimental reproduction of a red deer antler uniserial barbed point (photograph courtesy of Aimée Little)

Fig. 2. Blade core 10514, Sands of Forvie

Fig. 3. The Hermitage Adze (photograph courtesy of Aimeé Little)

\author{
[H1]RÉSUMÉ \\ [H1]ZUSSAMENFASSUNG
}

\title{
[H1]RESUMEN
}

Teoría del artesanado en Prehistoria: experimentos en el Mesolítico de Gran Bretaña e Irlanda, por Ben Elliott Este artículo reflexiona críticamente sobre el empleo del término 'artesanía' en el ámbito de la arqueología prehistórica, y su reciente protagonismo en una gran variedad de contextos analíticos. A partir de una breve evaluación de la forma en la que los prehistoriadores emplean el término 'artesanía', se hace necesario considerar el valor potencial de la 'teoría de artesanado', un creciente corpus interdisciplinar de bibliografía relacionada con las prácticas de 'hacer' que podría proponer nuevas interpretaciones sobre la cultura material dentro de un contexto arqueológico. Se utilizan tres casos de estudio originados a partir del Mesolítico de Gran Bretaña e Irlanda como vehículo para explorar este potencial en la práctica, precedidos por una amplia discusión que refleja estos esfuerzos y esbozos en otras posibles áreas de interés para investigaciones futuras. El panorama que emerge de esta discusión es altamente prometedor, un papel activo para los enfoques arqueológicos dentro de las actuales discusiones interdisciplinares sobre la 'artesanía', que contribuyen a nuestra comprensión contemporánea y los distintos enfoques que empleamos en el estudio de la cultura material en contextos arqueológicos.

${ }^{1}$ School of Archaeology, University College Dublin, Belfield, Dublin, Ireland Email: Benjamin.elliott@ucd.ie

Author contact: Benjamin.elliott@ucd.ie 